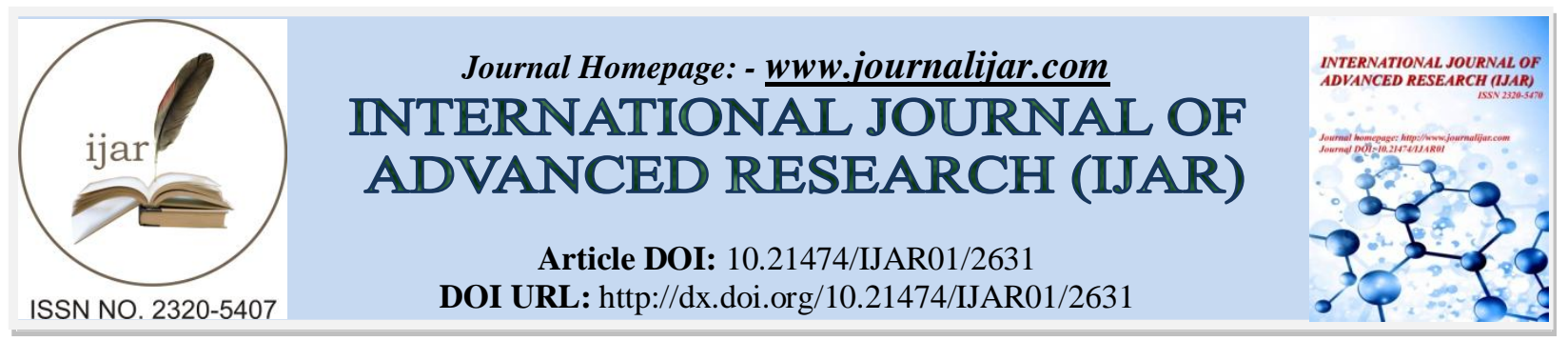

RESEARCH ARTICLE

\title{
SPORTS PARTICIPATION OF STUDENTS IN RURAL AND URBAN SECONDARY SCHOOLS OF DISTRICT ANANTNAG.
}

JAVAID AHMAD GANAIE.

\section{Manuscript Info}

Manuscript History

Received: 30 October 2016

Final Accepted: 29 November 2016

Published: December 2016

\section{Abstract}

Participating in school sports is an important means to increase physical activity among adolescents. While participation in schools can play an important role in increasing physical activity levels. school sports participation alone may not be sufficient to meet the current physical activity recommendations for adolescents. Therefore sports participation should not be seen as a replacement for physical education in schools but rather as a supplement to the solid foundation provided by physical education.

During the study the researcher visited to 30 secondary schools both rural and urban of district Anantnag. This study examines participation of rural and urban secondary school students of district Anantnag. It shows how participation of students varies in secondary schools because of socio-economic status and available sports facilities.During the research a questionnaire was given to the respondents and the response was recorded. Questions regarding sports facilities, participation, non participation, infrastructure, sports activities were asked.

Copy Right, IJAR, 2016,. All rights reserved.

\section{Introduction:-}

Most universities and colleges encourage students to participate in recreation activities during their leisuretime and often provide a wide range of sporting opportunities to cater for all levels and types of participants need. Universities and colleges often encourage participation in other physical recreational activities by students who are not interested in sporting activities. But the case is somewhat different with the secondary schools.

Sports is a playful, joyous and dynamic activity. Sports is important in all educational institutions as it supports academic objectives. The contribution of sports in secondary or other educational institutions cannot be over stated. According to Arnold, sport in school should be treated as a practice that has internal goals and standards rather than an institutional focus that tends to be more concerned with power, status and prestige.

The place of sport in schools has always been controversial and struggled to gain legitimacy and acceptance as a part of the formal curriculum. While some commentators argue sport has no place in the curriculum, others claim it is too important to be left to chance and, like other aspects of education, it can and should be pursued for its own intrinsic value. Many researchers like Updyke and Johnson [1970], Mclnally [2003], Newman [2005] among others are of the view that the participation in sports and other physical activities have positive co relations with academic performances among students. The following statement is apt to prove the above fact as Hendry et. Al state: 
Young people have mixed views about sport and may avoid participating, especially when a high degree of commitment and energy is required. It can be further complicated if their skill level is below that expected from significant others (Hendry, Shucksmith, Love \& Glendinning, 1993).

Like other rural and urban areas of our country there was a prominent difference in sports participation in rural and urban secondary schools of district Anantnag. There was as slight decline in the participation in rural secondary schools than urban because many of reasons regarding their economic, social, domestic obligations.

Hypotheses:-

There will be a significant difference in sports participation of students in rural and urban secondary schools.

\section{Objectives:-}

1. To trace the relationship between sports and secondary school curriculum.

2. Contribution of secondary schools towards the emerging growth of sports and physical education by student participation.

3. To know the reason of negativity or affinity of secondary school students towards spots participation.

\section{Methodology:-}

As every research demands a systematic method and procedure likewise this research adopts the following procedures including information regarding research design, source of data, sampling method, selection of subjects, collection of data, criterion Measures etc. A research becomes successful, accompanied and supported by some reliable and authentic data. The statistical analysis of the gathered data provides a well-knit picture of a complete and successful hypothesis as pre-selected by the researcher.

\section{Source of Data:-}

For the Present study the Subjects were selected from as different secondary schools both rural and urban areas of district Anantnag.

\section{Selection of Subject:-}

There are 30 subjects selected for the present study from both rural and urban areas of Anantnag district.

\section{Sampling Method:-}

The subjects were selected by simple random sampling method.

For the present study the standard Questionnaire gives two forced options in the form of 'yes' or 'no'.

\section{Collection of Data:-}

The data pertaining to the study was collected by administering the standard Questionnaire.

\section{Administrating of the questionnaire:-}

The Questionnaire was personally distributed in various students of both rural and urban secondary schools. This investigation has encouraging co-operation in this respect and the returns were very high.

\section{Distribution of questionnaire:-}

The return were very encouraging to the investigation the 30 were given to rural schools and 30 were given to urban secondary schools.

\section{Scoring of Data:-}

All the items except 1, 2,3,5,7 and 21 are positively awarded. All these items are given a score of ' 1 ' for positive responses except for items $1,2,3,5,7$ and 21 , in which case reverse is applicable (i.e.), The sum of these values gives the scores for the subject.

\section{Level of Significance:-}

In the hypothesis the level of significance at 0.05 of level of confidence was considered adequate for the purpose of this study. 
Table 1:-

\begin{tabular}{|l|l|l|l|l|l|l|}
\hline Group & $\mathrm{N}$ & Mean & S.D & M.D & SE $_{\mathrm{D}}$ & t-value \\
\hline Rural schools & 30 & 17.68 & 3.97 & & \multirow{3}{*}{$1.84 *$} \\
\hline Urban schools & 30 & 19.16 & 3.67 & 1.48 & 0.30 & \multirow{2}{*}{$4.84 *$} \\
\hline
\end{tabular}

*Significant at 0.05 level of confidence

t $0.05(48)=2.01$

From the above table the mean of the rural secondary school students was found 17.68 and the mean urban secondary school students was found 19.16. Standard Deviation of rural secondary school students was found 3.97 and the Standard Deviation of urban secondary school students was found 3.67. The standard error was found 0.30 and $t$ value was found4.84. With df 48 which is more than tabulation value at 0.05 (2.01) level of confidence.

Graph 1:- Showing mean and S.D of sports participation in rural and urban secondary schools

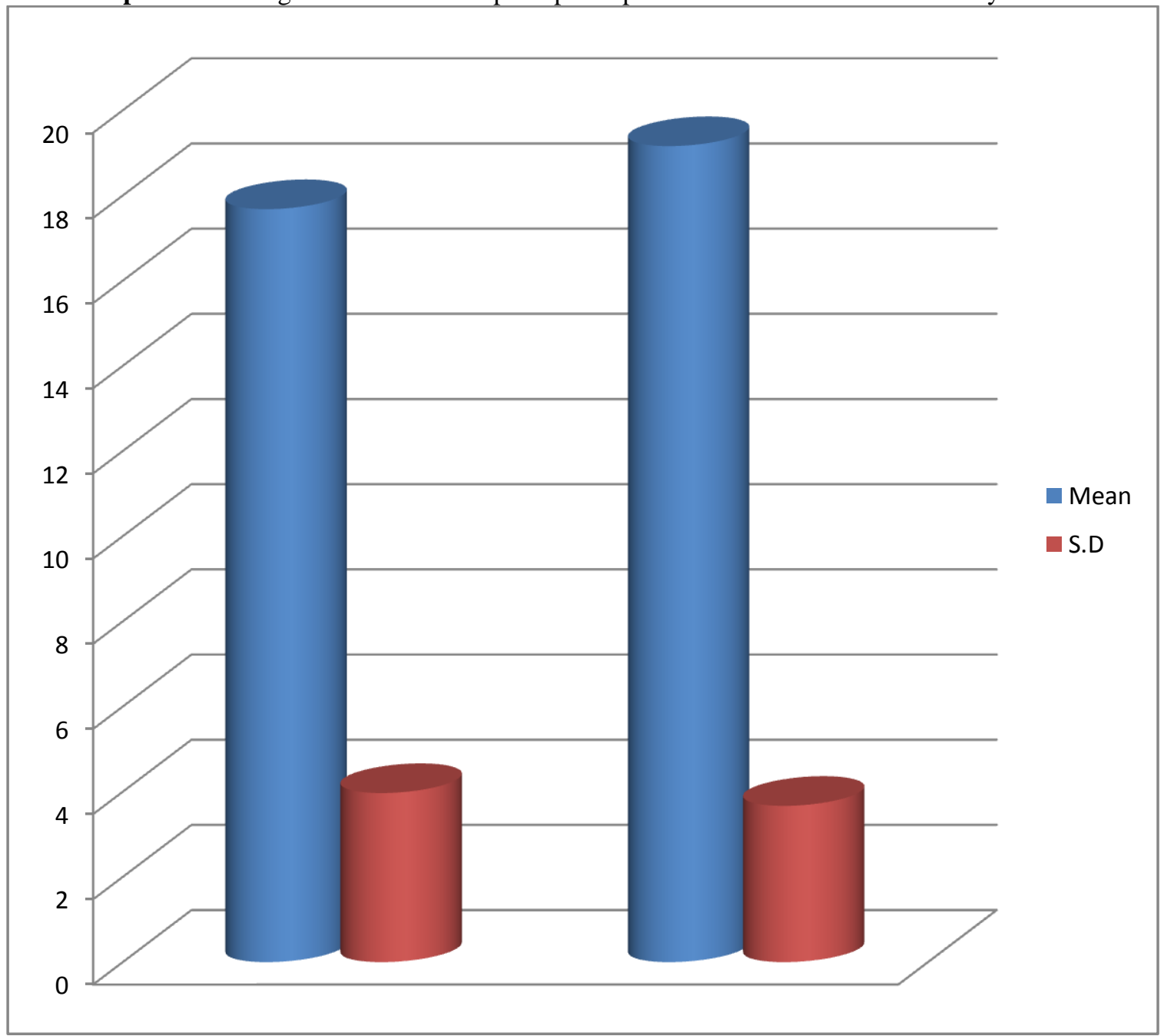

The mean of sports participation in rural secondary schools was found 17.8 and the mean of sports participation in urban secondary schools was found 19.16. The S.D of $1^{\text {st }}$ one found 3.97 and S.D. $2^{\text {nd }}$ was found 3.65. This indicated that

\section{Discussion of Hypotheses:-}

The present research aims to study the level of sports participation of students in rural and urban secondary schools. There is a significant difference found in the sports participation in rural and urban secondary school students. 
In the present study our first hypothesis that there is significant difference found in sports participation in rural and urban secondary schools has been found correct.

\section{References:-}

1. Arnold PJ (1968). Education, physical education and personality development. London: Heinemann.

2. Clarke ER (1977). Activities and games for tropical schools. London: Macmillan Education.

3. Durojaie, M. O. (1976). An introduction to educational psychology. Ibadan: Evan Brothers.

4. Ekperigin T, Uti JO (1982). A handbook for physical education for tropical schools and colleges. London: Macmillan.

5. Faw T, Belkin GS (1980). Child psychology. New York: Mc-Graw Hill.

6. Helms DB, Turner JS (1992). Exploring child behaviour. Philadelphia: WB Saunders..

7. Krogh SL (1994). Educating young children: Infancy to grade three. New York: McGraw-Hill.

8. McInally P (2003). Parents: Adopt positive role in youth sports. Retrieved March 8, 2007, from tos/schools/naia/genre/antopdf/implementationkit.pdf

9. Newman T (2005). Coaches' roles in the academic success of male students athletes. Retrieved January 16, 2007, from

10. www.thesportjournal.org/2005journal/vol8- No.2/SCJ-03-timnewman.

11. Schwartz LO (1990). Let's build a firmer partnership: Sports education. NASSP Bull. 19, 20. 